\title{
Introduction
}

\section{Core Aims}

By analysing the development of attitudes, legislative initiatives and actual policies in relation to post-execution punishment and other aggravated execution practices, this volume aims to establish the important role the criminal corpse played within penal policy in the eighteenth and early-nineteenth centuries. A variety of execution procedures, involving either a more painful death or further punishment of the criminal's corpse after death (or both), were extensively discussed in this period. Many of these were never actually used in England and Wales but a limited range of post-execution punishments-most notably dissection and hanging in chains-were widely utilized by the courts and the criminal justice authorities in various contexts between 1700 and the 1830s. Using newly collected data on court sentences involving post-execution punishments covering every county in England and Wales, this volume presents the first systematic analysis of the ways the use of the criminal corpse added a new depth to the capital sanctions imposed on the bodies of offenders in this vital period.

This research forms part of a much broader project funded by the Wellcome Trust entitled 'Harnessing the Power of the Criminal Corpse', which focused mainly on the period from the late-seventeenth to the nineteenth century and explored the social, medicinal, symbolic and curative power of the criminal corpse, as well as its use for judicial/penal purposes. In particular the arguments presented here intersect with those

P. King, Punishing the Criminal Corpse, 1700-1840,

Palgrave Historical Studies in the Criminal Corpse and its Afterlife, DOI 10.1057/978-1-137-51361-8_1 
put forward in two detailed studies by other members of the Wellcome project team-Elizabeth Hurren's volume on 'Dissecting the Criminal Corpse' and Sarah Tarlow's work on hanging in chains, both of which cover much the same sub-period as this volume-the eighteenth and early-nineteenth centuries. ${ }^{1}$ These two volumes focus on the journey of the criminal corpse after the formal legal process was completed, uncovering, for example, the remarkably varied and sometimes central role that penal surgeons played in the execution process, and the long-term impact of hanging offenders' corpses in chains at prominent points in the landscape. Readers who want to trace the journey, and frequently the diaspora, of the corpses of executed criminals after the criminal justice system had made the decision to subject them to post-execution punishments should refer to Hurren and Tarlow's work as well as to the broader comparative volume $A$ Global History of Execution and the Criminal Corpse edited by Richard Ward and the monograph produced by two other scholars who are also Wellcome project members, Owen Davies and Francesca Matteoni, entitled Executing Magic: The Power of Criminal Bodies. ${ }^{2}$ This volume, by contrast, centres on the criminal justice dimension of post-execution punishment and of its less frequently used partner: rituals involving aggravated pre-execution practices. It looks at both penal debate and penal practices, at the reasons why these punishments were, or were not, adopted by the legislature and at the changing sentencing policies that resulted from those laws that were eventually passed. Although it also refers to the later stages of the criminal corpse's journey, and occasionally offers insights into the discretionary decisions made by those responsible for carrying out post-execution punishments (such as the surgeons' decisions about when to use the ultimate punishment of dissection followed by skeletal reconstruction and public display) the main aim is to provide, for the first time, a detailed history of aggravated and post-execution punishment in an era when the latter played an important role in penal policy.

The resulting analysis, it will be argued, not only adds a vital new dimension to the history of capital punishment in the eighteenth and nineteenth centuries, but also forces us to reassess some of our broader models of penal change and of the logic and chronology of the process by which capital punishment was reformed. As we will explore further in Sect. 3 of this chapter and the conclusion to the whole volume, historians relative neglect of the history of post-execution punishment has led some to embrace too simple a model of the transition from a terror-based public 'early modern' phase to a more private and humane 'modern' one. ${ }^{3}$ 
Moreover a lack of information and analysis about the timing of the collapse of the use of certain post-execution punishments has meant that other historians have put too much emphasis on the 1830s as the key moment in the decline of capital punishment. ${ }^{4}$ Equally the growing use of post-execution punishment in later eighteenth-century Britain challenges various models of penal change that are based on underlying assumptions about long-term unidirectional changes-either in sensibilities towards violent punishments, or in the development of new technologies of power and social control that focused on the mind rather than the body. ${ }^{5}$

\section{Historiographical CONTEXT}

The widespread use of the death penalty and the fact that large numbers of offenders were executed on the gallows has long been seen by historians as an important (and some would say central) aspect of social relations in the eighteenth and early-nineteenth centuries. ${ }^{6}$ 'The rulers of eighteenthcentury England', Douglas Hay argued in his seminal article, Property, Authority and the Criminal Law 'cherished the death sentence .... This was the climactic moment in a system of criminal law based on terror'. ${ }^{7}$ The large ambivalent crowds that gathered at executions, the problems the authorities had in directing them, the painful process of the execution itself and the changing attitudes of various social groups to capital punishment have also been subjected to detailed analysis, most notably in Vic Gatrell's much acclaimed book, The Hanging Tree. ${ }^{8}$ The 'Bloody Code', which by the mid-eighteenth century had made a huge variety of offences into capital crimes, and the subsequent campaign for its reform, have also received much attention from historians. 9 So has the pardoning process which, by enabling many capital convicts to avoid the gallows, helped to create one of the main paradoxes of the eighteenth-century criminal justice system-that while the number of capital offences steadily increased, the number of people actually hanged did not. ${ }^{10}$ However, historians of crime and justice have almost exclusively focused on the breadth of the capital punishment system-on the number of offenders who were executed and on the wide range of offences for which it was possible to receive the death penalty. By contrast they have largely neglected another important dimension-the depth of the capital punishment process - that is, the degree to which it was not simply about hanging but also about other execution practices that either exacted further punishment on the corpse of the offender after their death on the gallows, or added aggravation to the sentence by inflicting 
various forms of pain (such as breaking on the wheel) on the convict before his or her life had ended. One of the main aims of this volume is to redress this balance.

Some particular aspects of the history of post-execution punishment in this period have already been discussed by historians of the eighteenth century. The tiny number of murderers and other capital offenders who were subjected to burning at the stake have, for example, recently received some attention ${ }^{11}$ and the much more widely used post-execution punishments of dissection or gibbeting have been discussed in passing. ${ }^{12}$ However, no coherent analysis of this aspect of the capital punishment system has yet been written. Although, as we will see in Chap. 2, Randall McGowen has recently begun to explore the ways this issue was discussed in the first half of the eighteenth century, ${ }^{13}$ the vast majority of the pre-1750 writings that advocated the introduction of more aggravated forms of execution have been almost completely neglected by historians ${ }^{14}$ and the few contemporary writers that have been quoted have often been written off as 'foredoomed to failure' without being systematically studied. ${ }^{15}$ Moreover, the growing depth of capital punishment in the main era during which post-execution punishment was a legislatively required and frequently used part of penal policy, the period between 1752 and the early 1830s, has also been largely neglected. The two most important legislative moments - the 1752 Murder Act which made the dissection or gibbeting of murderers' corpses compulsory and the Anatomy Act of 1832 which put an end to the former practice-have received some attention. ${ }^{16}$ However, no serious discussion has yet been offered of the century-long debate on aggravated execution punishments; of the long-term origins of the Murder Act and its relationship to the problems created by the growth of the Bloody Code; of the many other post-1752 legislative initiatives that attempted to introduce (or modify) the use of post-execution punishments ${ }^{17}$; of the reasons why the post-execution punishment regime codified in the Murder Act lasted for so long, or of the number and types of offenders that were subjected to such punishments between 1752 and 1832. Whilst the extent of capital punishment has been studied in detail, the various ways in which greater depth was added to 'the spectacle of the gallows' in England has not received anything like the same attention.

This is surprising for two reasons. First, there was clearly extensive contemporary debate about the need to introduce post-execution or aggravated execution practices. A very considerable number of earlyeighteenth-century publications on penal policy argued in favour of 
(and helped to instigate legislative initiatives designed to introduce) both post-execution punishments and other aggravated forms of the death penalty such as breaking on the wheel, which were still widely practiced on the continent ${ }^{18}$ but which were not part of customary penal practice in England. The much quoted 1701 pamphlet Hanging Not Punishment Enough, ${ }^{19}$ which advocated not only breaking on the wheel but also starving to death and hanging in chains, has usually been treated by historians as highly exceptional. However, (as Chap. 2 will indicate) a closer inspection of the pamphlet, periodical and newspaper sources suggests that this anonymous pamphlet was part of a much larger and longer-running discourse. $^{20}$ Although many of these late-seventeenth and early-eighteenth-century writers discussed the possibility of replacing hanging with other non-capital forms of punishment, the starting point for most of these works was the writer's severe doubts about the effectiveness of just hanging the offender. 'Hanging is nothing at all' a pamphlet recommending 'sharper deaths' complained in 1695. 'Much gentler and less painful than bed-death', mere hanging involved 'so little terror ... in itself' that it seemed to the condemned to be 'a most easy death. ${ }^{21}$ Four decades later this issue was still being widely discussed. The 'quick dispatch' of hanging, one writer noted was 'so slight and unterrifying' that 'an execution that is attended with more lasting torment' was surely necessary. ${ }^{22}$ 'Even the gallows cannot terrify' the Gentleman's Magazine observed in 1738, 'death without pain can be terrible to none', ${ }^{23}$ and this theme that 'hanging only signifies nothing' was echoed in several London and provincial newspaper articles that, having first pointed out that 'the gallows will not deter' went on to argue that 'these shocking barbarities undoubtedly deserve a severer death than bare hanging. ${ }^{24}$

Although these writings almost certainly helped to prepare the ground for the Murder Act of 1752, the doubts they expressed about the efficacy of the gallows were not raised in relation to murderers alone. The 'shocking barbarities' referred to in the later 1730s were committed by highwaymen, and the full title of the 1701 Pamphlet-'Hanging Not Punishment Enough for Murtherers, High-way Men, and House-Breakers Offered to the Consideration of the Two Houses of Parliament' - makes it clear that aggravated forms of capital punishment and/or post-execution punishment were also thought by some to be necessary for many offences that did not involve the taking of life. Nor did this issue disappear after the 1752 Murder Act. The context began to change after mid-century. Continental punishments such as breaking on the wheel, which were designed to ensure 
that the convicts 'felt their death', were much less likely to be seriously advocated after that point, but the possibility of further extending the use of post-execution punishments - and particularly of public dissection-was still being widely advocated in the late-eighteenth century and beyond. In 1786 the Prime Minister himself supported a bill introduced by William Wilberforce designed to extend the post-execution punishment of dissection from murder to several other offences including burglary and highway robbery, and similar (if less well-supported) attempts were made in 1796 and in $1830 .^{25}$ Although from the mid-eighteenth century onwards critics of capital punishment increasingly emphasized the need to replace it with non-capital options, such as transportation, life imprisonment with hard labour or solitary confinement, ${ }^{26}$ one of the core themes of many early-eighteenth-century critiques-that hanging was not punishment enough and needed additional post-execution punishments to be attached to it-clearly continued to have resonance, and to gain considerable support within governing circles, not only in the 1780s and 1790s but also well into the nineteenth century (Chap. 4).

The second reason why it is so surprising that this subject has been neglected by historians is that the period from the mid-eighteenth century to the 1830s witnessed the high point of post-execution punishment in Britain. Following the Murder Act of $1752,{ }^{27}$ all convicted murderers were either dissected or gibbeted, while the latter punishment continued to be used on a discretionary basis against considerable numbers of major property offenders, as it had been since at least the beginning of the century. This meant that large numbers of offenders underwent these punishments. In England and Wales more than 1000 offenders were dissected or gibbeted under the Murder Act, and between 1740 and 1800 another hundred or so were gibbeted for other offences. ${ }^{28}$ In most parts of England and especially around London, which was the epicenter of the Bloody Code, ${ }^{29}$ the public would have been all too aware of these punishments. The regular use for at least 80 years of formal sentences of public dissection, and the widespread eighteenth-century practice of hanging the corpses of the condemned on gibbets placed in prominent places, meant that post-execution punishment had both a highly visible and, in the case of gibbeting, a very long-lasting impact on public life. Approaching eighteenth-century London by either road or water usually involved passing at least one gibbet (and sometimes several) and the capital's reputation as 'the city of the gallows' ${ }^{30}$ suggests that post-execution punishment was much more important in helping to shape public 
consciousness than its relatively brief treatment in existing historical work would imply.

In order to redress this imbalance this volume looks in detail both at changing attitudes to aggravated and post-execution punishments and at the ways those punishments were used by the courts and shaped by the judicial authorities. It surveys the different types of post-execution punishments and other aggravated execution practices that were suggested by contemporaries, the reasons why they were advocated, the debates in Parliament about the introduction of such policies, the origins of the 1752 Murder Act, and the ways that this major legislative initiative was actually put into practice. It also analyses the changing use of different post-execution punishments over time and the reasons for their final abandonment between 1832 and 1834, before then attempting to identify the main underlying ideas/presuppositions that led contemporaries first to advocate these punishments and then to turn decisively away from their use. The English state made a unique attempt to harness the power of the criminal corpse in the eighteenth and early-nineteenth centuries and the aim of this volume is not only to explore and explain that phenomenon for the first time, but also to try to understand the important, but largely unexplored, role the Murder Act played within the broader capital punishment system well into the nineteenth century. In the process this analysis will also suggest that the history of post-execution punishment raises a number of important questions about many of the broader models of penal change often used by criminal justice historians.

\section{The Broader Questions Raised by the Study of Post-execution Punishment}

The fact that the origins, nature and role of the Murder Act have been relatively neglected by historians partly reflects their deep ambivalence towards it, and the awkward questions it frequency raises about the frameworks of explanation they have used to account for penal change in the eighteenth and early-nineteenth centuries. Neither of the two models historians have most frequently used to explain the changing nature of capital punishment in the eighteenth and early-nineteenth centuries fits comfortably with the increased use of post-execution punishment that occurred between 1752 and the early 1830s as a result of the Murder Act. 
The first of these models is based on the work of Norbert Elias, which stressed the important role that cultural values and sensibilities played in shaping changes in attitudes to violence. ${ }^{31}$ Although this model, and in particular Pieter Spierenburg's detailed application of it to the history of penal policy, has been subjected to considerable criticism by some historians who prefer to stress the role of specific economic, political or governmental factors, it has rightly maintained considerable purchase amongst those working on the history of capital punishment. Spierenburg, has argued that 'an original positive attitude towards the sufferings of convicts slowly gave way to a rising sensitivity, until a critical threshold of sensibility was reached in the nineteenth century - the growth of that sensibility being the main reason why aggravated execution rituals and the display of criminal corpses were gradually abolished. ${ }^{32}$ Similarly, Paul Friedland in his chapter on 'Executions in the Age of Sensibilite'-part of a broader study entitled Seeing Justice Done; The Age of Spectacular Capital Punishment in France-has recently pointed out that in the first half of the eighteenth century ... the seventeenth-century ideal of sensibilite, which had originally been conceived of as a unique gift of the privileged few, was increasingly being understood as a kind of automatic predisposition to compassion, a natural human reflex that made it impossible for one human being to witness the suffering of another without suffering themselves. ${ }^{33}$ This idea - that the eighteenth century witnessed a growth in sensibility towards other's pain and an increasing desire to put restraints on all forms of violence, including those inflicted by the criminal justice system-is, however, of very limited use in explaining the Murder Act. If, as John Beattie has argued, the more severe and public forms of post-execution punishment introduced by the Act were designed, 'to reassert the centrality of hanging and deterrence by terror at the heart of the English penal system, ${ }^{34}$ how does this fit with the notion that the eighteenth century witnessed a growing sensibility towards violence-a 'mental sea change', which condemned cruelty in punishment as fundamentally 'unacceptable in a civilized society'? ${ }^{35}$ This idea, which as James Cockburn has pointed out, was widely discussed by Enlightenment commentators attempting 'to distance their own era from the violence and insensitivity of earlier ages' ${ }^{36}$ is extremely hard to reconcile with the 80 years of public post-execution punishments that followed the 1752 Murder Act.

The increased use of gibbeting and dissection against murderers and property offenders in the period 1752-1832 was, Ruth Richardson has recently argued, not only designed to overtly flout the customary concern 
to honour the bodies of the dead, which manifested itself in contemporary funereal rituals, but was also intended, implicitly at least, to deny the soul a resting place by refusing to allow the intact burial of the corpse. ${ }^{37}$ These post-execution punishments were essentially acts of violence. This was, to quote Richardson, 'public corpse abuse under the protection and patronage of the state,' which exposed the dead to public indignity, maltreatment and dismemberment. ${ }^{38}$ The increased use of highly public dissections and of gibbeting in the second half of the eighteenth century, and the continued use of penal dissection throughout the first third of the nineteenth century, raises questions about the ways Spierenburg and others have applied Elias's model to penal policy in England. As Richard Ward has pointed out in his recent work on the origins of the Murder Act, 'by imposing a more severe and exemplary form of punishment on convicted murderers, the Act in some ways cuts across the growing humanitarianism, civility and urbanity which several historians have posited as defining features of penal reform in the eighteenth and nineteenth centuries. ${ }^{39}$

The other major model of penal change that is widely used by historians of this period-Michel Foucault's notion that elaborate and violent forms of public execution were increasingly regarded as both unnecessary and dysfunctional as forms of governance after the mid eighteenth centuryalso offers little help in explaining either the passing of the Murder Act or the growing use of public post-execution punishments in the 80 years that followed it. ${ }^{40}$ Foucault's model of a transition from punishments centred on the body to those designed to discipline and reshape the mind has much to offer, but the transition was not as smooth or as unproblematic as he implies. His failure to address the questions raised by the passing of the Murder Act has made his work less applicable to the English case. His portrayal of the transition in penal policy from 'an art of unbearable sensations' to 'an economy of suspended rights' may or may not fit the evidence in France, but the work presented here suggests that when applied to England his ideas fit poorly with the chronology of change and have an air of inexorability that does not fit well with the evidence. ${ }^{41}$ After his famous opening description of the tortured public dismemberment of Damiens in 1757, Foucault argued that 'a few decades saw the disappearance of the tortured, dismembered, amputated body ... exposed alive or dead to public view. The body as a major target of penal repression disappeared. By the end of the eighteenth and the beginning of the nineteenth century, the gloomy festival of punishment was dying out. ${ }^{42}$ Yet while, as we will see, this chronology has at least some resonance with the history of gibbeting in 
England, it does not explain the continuance of highly public criminal corpse dissections throughout the first three decades of the nineteenth century. The history of capital punishment, and the role of post-execution punishment within it, are more complex and less unilinear than this model suggests, and for this reason the conclusion to this volume will also argue that David Garland's model of changing 'modes' of capital punishment (which borrows quite heavily from Foucault) may need to be rethought. ${ }^{43}$

In his seminal paper 'Modes of Capital Punishment; The Death Penalty in Historical Perspective' Garland's analysis of the period from the sixteenth to the nineteenth centuries distinguishes two specific, and 'sharply differentiated' modes of capital punishment-the 'early modern' and the 'modern'-each of these modes being associated not only with different periods but also with distinctive forms of social organization and state development. ${ }^{44}$ The 'early modern' mode was, he argues, characterized by the depth and intensity of the capital punishment rituals used across Europe, seen in the horrifying and extended execution and post-execution practices and in the use of elaborate and varied public ceremonies designed to proclaim the power and sovereignty of the state during a period when it was often weak and vulnerable. ${ }^{45}$ Needing to develop tactics that would strike fear into the hearts of their enemies, early modern states were endlessly inventive in their elaboration of these execution processes and in ensuring that the bodies of the most serious offenders continued to be punished even after they were dead. ${ }^{46}$ This 'old ... early modern style' of death penalty had disappeared, Garland argues, by the early-nineteenth century and was replaced by what he terms the 'modern' mode in which capital punishment was used less extensively and had much less depth as a process. As the death penalty changed from being a vital instrument of rule to becoming simply another potential sanction amongst a range of penal options, the use of capital punishment was largely confined to cases involving murder or treason. It also became increasingly private and humane as elements of aggravated or post-execution punishment were abandoned. In Garland's analysis this 'long-term movement toward a more restrained, refined and reduced death penalty' followed a definite 'developmental pattern' linked to state formation, rationalization, liberalization and democratization' as well as to the broader processes of 'civilization and humanization. ${ }^{47}$ However, this two-phase model pays little attention to the potentially unique nature of the long eighteenth century as a separate era in British penal history. 
Detailed work by historians of the long eighteenth century has already established that the English criminal justice system developed a number of important new characteristics during that period. Execution rates, which had peaked at very high levels in the late-sixteenth and early-seventeenth centuries, had fallen to unprecedentedly low levels by the early-eighteenth century. ${ }^{48}$ However, the same period witnessed the growth of the so-called 'Bloody Code' as a succession of parliamentary acts rapidly increased the number of relatively minor offences that could be punished by death. ${ }^{49}$ The long eighteenth century also witnessed the creation of a much more finely differentiated punitive system. The penal regimes of the sixteenth and seventeenth centuries had relied mainly on physical punishments such as whipping, branding and hanging, but the introduction, and widespread use, of transportation and imprisonment in the eighteenth century added new flexibility to the sanctions available and encouraged the growing use of pardoning in capital cases. ${ }^{50}$ Moreover, as will become clear as this study unfolds, the period from the late-seventeenth century to the early years of the nineteenth also witnessed a considerable expansion in the depth of capital punishment. Aggravated pre-execution techniques were much discussed and two forms of post-execution punishment were increasingly used as the century progressed, creating (for murder at least) a new level of differentiation within the capital punishment system that paralleled the similar change that took place amongst non-capital sanctions as the new intermediate sanctions of transportation and imprisonment came to dominate punishments for property crime. ${ }^{51}$ When this new post-execution punishment-based perspective is added to the detailed work already done by a wide range of eighteenth-century criminal justice historians, ${ }^{52}$ it becomes clear, I will argue, that we need to rethink Garland's two-stage model and to acknowledge that the period from the late-seventeenth century to the early nineteenth was a distinct phase in the history of capital punishment rather than just a time of gradual transition from an early modern to a modern mode. $^{53}$

The study of post-execution punishment also raises important questions about the very different perspective offered by Gatrell in his influential book The Hanging Tree. ${ }^{54}$ Gatrell's explanation of the transformation of capital punishment policies contrasts sharply with that put forward by Garland. The latter focused primarily on the long-term forces behind changing capital punishment practices. The transition from early modern to modern modes occurred, Garland argued, 'within a larger arc of development' and of state transformation, as 'the newly stabilized states of the late-seventeenth 
century gave way to the enlightened monarchies of the eighteenth century and eventually to the unified and bureaucratized nation states of nineteenth century Europe'. ${ }^{55}$ Gatrell, by contrast argued for extreme discontinuity as the key to understanding penal change, at least in England. 'There has been no greater nor more sudden revolution in English penal history', he argued, 'than this retreat from hanging in the 1830s,' and that retreat was quite simply, in his view, a short-term reaction to the very high numbers of convicts being sentenced to death in the 1820s and the impossibility of hanging significant proportions of them without alienating public opinion. ${ }^{56}$ For Gatrell this was a dramatic watershed and was very definitely not a product of the medium- to long-term factors foregrounded by Foucault, Elias, Spierenburg or Garland. The capital code 'did not collapse because of a revolution in sensibilities' he argued, but rather 'there was a revolution in sensibilities because the code was collapsing already. ${ }^{57}$ However, as Chap. 3 will make clear, fundamental changes in the use of post-execution punishments, in hanging policies and in the use of techniques such as scene-of-the-crime hangings had all occurred during the half-century before Gatrell's watershed. The analysis presented here, I will suggest in the final chapter, therefore gives considerable further weight to the recent critiques of Gatrell's work produced by Simon Devereaux and others. ${ }^{58}$ Moreover, another weakness of Gatrell's watershed theory-his failure to address the fact that it lacks any real purchase as an explanation of the decline of capital punishment elsewhere in Europe-is also highlighted by another broad sub-theme that gradually emerges from this volume. Although significant differences between British and continental practice can clearly be identified, overall the detailed study of aggravated and post-execution policies presented here suggests that the English capital punishment reform process was much less dissimilar to that found on the continent than either contemporary commentators or many subsequent historians have assumed.

In exploring both the widespread advocacy of torment-based aggravated execution techniques in the first half of the eighteenth century, and the large-scale compulsory use of post-execution punishment in the 80 years after the Murder Act, this study is therefore focusing on aspects of punishment policy that offer a rare opportunity to test the applicability and explanatory capacity of the broader models of penal change on which historians of the period have mainly founded their ideas. In the process it will also offer new perspectives on the Murder Act itself, the passing (and timing) of which has proved difficult for historians to fully explain. In his article on 'Punishment and Brutalization in the English Enlightenment', 
for example, Cockburn concluded that 'no single episode better illustrates the inconsistencies and contradictions implicit in attempts to accommodate the "traditional" and "enlightened" strands of eighteenth-century penal thinking than the Murder Act'... The timing seems ... extraordinary'. ${ }^{59}$ Philip Rawlings also found the Act problematic and contradictory. 'In spite of the Murder Act', he observed, 'there was generally a shift away from such calls for increased severity by mid-century' ${ }^{60}$ However, through an exploration of the Act's key role in creating a new scale of capital punishment penalties by introducing a significant differentiation between the forms of execution used on property offenders and those imposed on murderers, this volume will suggest that the Act was neither inconsistent nor contradictory. On closer study, it will be argued (Chap. 5), it is clear that the Murder Act was both a logical extension of the Bloody Code, and played an important role in legitimizing and maintaining that code.

\section{Plan of THE BoOK}

Five major types of mainstream criminal prosecutions sometimes resulted in sentences involving aggravated or post-execution punishments during these years - trials for high treason; for petty treason; for piracy and other crimes on the high seas tried by the Admiralty Courts; for murder; and for capital property offences deemed heinous enough by the Assizes or Old Bailey judges to be worthy of gibbeting as well as hanging. ${ }^{61}$ The final two categories in this list-murder and major capital crimes against propertyattracted by far the most debate about the need for aggravated or post-execution punishments and accounted for the vast majority of the criminal corpses that were eventually subjected to those processes (as the statistics discussed in Chap. 3 will indicate). These two categories were also the primary targets of the most important legislative initiatives involving the extension of post-execution punishment that were discussed during this period - the Murder Act of 1752, which made dissection or hanging in chains compulsory for those found guilty of homicide, and the unsuccessful Dissection of Convicts Bill (passed by the House of Commons but not by the Lords in 1786) that attempted to extend the former punishment to the corpses of executed burglars, robbers and other offenders. The bulk of this book will therefore focus on these final two categories and to a lesser extent on the practice of burning offenders at the stake either for specific types of murder - the killing of a husband or master - or for property crimes related to coining. The relatively small number of cases involving aggravated 
execution and post-execution practices in relation to treason and to Admiralty Court offences will not receive the same level of attention here, but will be included in the statistical analysis (Chap. 3) and the discussion of penal change in order to offer a more fully rounded model of the rise and fall of pre- and post-execution punishment between 1700 and the 1830s.

After briefly reviewing the use of post-execution punishments before 1700 in the final section of this chapter, the study will then move on in Chaps. 2, 3 and 4 to look in detail at the period from 1700 until the final abandonment of the two main post-execution punishments-dissection and gibbeting-in the 1832 Anatomy Act and the 1834 Act for the Abolition 'Hanging the Bodies of Criminals in Chains'. ${ }^{62}$ Drawing on all the available forms of contemporary discourse-pamphlets, works by legal commentators, articles in newspapers and periodicals, judge's comments, parliamentary debates and reports etc.-Chap. 2 will trace the chronological development of the debates about the introduction of either aggravated pre-execution policies or about the post-execution punishment of the criminal corpse, particular attention being paid to the key moments when legislative change was either achieved or seriously debated. It will focus on the period from the 1690s to the passing of the Murder Act of 1752 , when a wide variety of aggravated and post-executions punishments were discussed, and will end with an analysis of the reasons for the passing of the 1752 Act, which made dissection and hanging in chains a formal part of sentencing policy for the first time. In Chap. 3 the analysis will shift temporarily from discursive formations and legislative initiatives to the actual decisions made by the courts. The primary focus will be the period from 1752 to the 1830 s and the use that the courts made of sentences involving post-execution punishments in the key period between the Murder Act and its repeal. A previously neglected source-the Sheriff's cravings - will be used to create a detailed statistical analysis of two broad patterns: changes across time in the use of punishments such as gibbeting and dissection, and geographical variations in sentencing policies. Chapter 4 analyses the same period but moves from this quantitative focus on the patterns of court decision making back to a qualitative study of changing discourses and debates about policy. It focusses on the key developments of the period between the passing of the Murder Act and its repeal in 1832, particular attention being given to both the later eighteenth- and early-nineteenth-century debates about extending the post-execution punishments laid down in the Murder Act to include major property offences, and the growing doubts about gibbeting, and eventually about 
dissection, which culminated in the final abandonment of post-execution punishment in the early 1830s. The conclusion then highlights the various ways in which the study of the punishment of the criminal corpse and of aggravated execution policies challenges both the eighteenth-century reformers own key 'civilizing' narrative, and many of the models modern historians have developed about the chronology of penal change. It also explores the relationship between changes in the quantity of capital punishment (i.e. in the frequency of executions) and changing policies in relation to the quality of that punishment (i.e. in the level of post-execution punishments inflicted on the corpse of the condemned), and argues that, right up until the penal reforms of the 1830s, post-execution punishment was seen as an important part of the penal landscape and as a vital means of differentiating between the punishment of murder and that of other more minor capital crimes.

\section{Post-execution Punishment Before The Early-Eighteenth Century}

A variety of different forms of post-execution punishment and of aggravated execution practices that often involved further punishment of the convict's corpse after death were used in England in the period leading up to 1700 . However, outside cases involving treason or petty treason, the repertoire of such punishments was much smaller than that found in most other European countries, and the options that were available in England were also used much less frequently with one notable exception-a brief period in the mid-sixteenth century when large numbers of British heretics were burnt at the stake (a punishment deemed particularly appropriate because it was also an effective post-execution punishment leaving no remains for burial). ${ }^{63}$ The execution practices used in medieval England are difficult to analyse because they were poorly documented, often non-statutory and sometimes highly localized. It is unclear, for example, whether the practice of executing felons by drowning, found in fourteenth-century Kent, was also in use elsewhere. ${ }^{64}$ Some longestablished local practices such as the Halifax 'gibbet', a relatively humane mechanism very similar to a guillotine, continued to be used fairly extensively until the mid-seventeenth century. ${ }^{65}$ Everywhere else in England and Wales beheading, which was regarded throughout Europe as 
involving less dishonour than hanging, was usually reserved for high status offenders. ${ }^{66}$

Pieter Spierenburg's suggestion that prolonged death on the gallows was 'practically unknown' in early modern England slightly exaggerates the differences between Britain and the continent. ${ }^{67}$ The practice of boiling convicted poisoners to death, for example, was briefly given statutory backing in 1531 and several offenders, including a Norfolk maid-servant who had poisoned her mistress, suffered this punishment before the statute was repealed in $1547 .{ }^{68}$ Later attempts to revive it were not, however, successful $^{69}$ and although examples of the hand of the condemned being cut off and nailed up in a public place can be found in sixteenth-century England, and as late as the mid-eighteenth century in Scotland, there can be no doubt that by the later seventeenth century aggravated forms of execution designed to torment the convict were very rare in England, unless the offender had committed a treasonable offence. ${ }^{70}$ Historians working on early modern punishment in continental countries such as Germany, Holland and France-where breaking on the wheel, boiling and burning, not to mention burying alive, starving to death and drowning often remained in use well into the eighteenth century and beyond ${ }^{71}$ have therefore drawn a very different picture to those working on England and Wales. In the later sixteenth and seventeenth centuries the English gradually extended their use of two forms of aggravated execution-gibbeting and dissection-that were not based on increasing the torment experienced by the condemned, but were entirely post-execution punishments targeted at the criminal corpse. These punishments, far from fading away, were growing in importance by the early-eighteenth century. Although, as we will see, many early-eighteenth century English commentators argued vehemently for the introduction of continental torment-inducing execution practices, they were not successful. Post-execution dissection or hanging in chains remained the central forms of aggravated execution procedure acceptable to those who shaped English capital punishment procedures in relation to murderers and property offenders throughout the eighteenth century.

Both of these punishments had long histories by 1700. Gibbeting for both murderers and other heinous offenders such as violent robbers had been practiced since at least the thirteenth century. ${ }^{72}$ The precise methods by which offenders were gibbeted (or hung in chains as the process was more commonly described) and the various policies that were developed in relation to location, construction and so forth will be not discussed in detail 
here because Sarah Tarlow's forthcoming book Hung in Chains; The Golden and Ghoulish Age of the Gibbet in Britain will deal with this subject in detail. However, the core characteristics of gibbeting-the secure and highly visible suspension of the corpse in a public location (and often for many years) in order to create a lasting warning and example, were well established by the seventeenth century. ${ }^{73}$ In the later Middle Ages the gibbeting of the condemned while they were still alive was occasionally used to punish particularly heinous premeditated murders, ${ }^{74}$ but there is no serious post-1600 evidence of this in England. ${ }^{75}$ The English were not, however, averse to such practices when they dealt with colonial slaves. Following a slave rebellion in 1736 the authorities in Antigua burned fifty-eight rebels alive and broke five of them on the wheel, while a further six were reported to have been 'hung in chains upon gibbets and starved to death (of whom one lived nine nights and eight days without any sustenance)'. After death their corpses were subjected to further punishment as 'their heads were then cut off and fixed on poles, and their bodies burnt'. ${ }^{76}$ Since convicted slaves were also starved to death on gibbets or had their heads displayed on poles in many other eighteenth-century British colonies, even though their offences were often more routine, ${ }^{77}$ the boasts of many eighteenth-century English writers that, in contrast to 'the scenes of barbarity ... so often exhibited' on the continent, 'such tormenting and lingering deaths cannot mix well with our constitution,' need careful evaluation. Englishmen may have been fond of highlighting 'the lenity of our laws, the boast and felicity of our constitution', but their unwillingness to embrace torment-based execution practices was highly dependent on context, even though they steadfastly refused to acknowledge this. ${ }^{78}$ This said, however, in England and Wales at least the rhetoric was usually matched by the reality, and gibbeting remained very much a post-execution punishment until it was completely abolished in 1834 .

Before the Murder Act of 1752 hanging in chains, as gibbeting was most commonly termed, even though it usually involved the use of a metal cage, was based on customary law and more specifically on the belief that the bodies of condemned men were at the King's disposal. ${ }^{79}$ It was imposed by a form of executive order on the basis of customary procedure, rather than being laid down by statute as a formal punishment, and it is unclear whether it was always (or even usually) recorded in court when sentence of death was passed. ${ }^{80}$ This doubt about the proportion of gibbetings that were announced by the judges and therefore formally recorded in the surviving assize records, makes it very difficult to gauge how 
frequent the practice was in the late-sixteenth and seventeenth centuries. On the basis of finding only one instance in the assizes records of the five Home circuit counties between 1559 and 1625, and just a single isolated example in the seventeenth-century Oxford Circuit records, Cockburn has argued that gibbeting was uncommon before the eighteenth century. ${ }^{81} \mathrm{It}$ is possible, however, that it was quite frequently not recorded by the courts' clerks and therefore largely invisible to the historian because other non-court sources, such as newspapers, which would later record such events quite extensively, were not in existence until the final years of the seventeenth century. Gregory Durston has argued, by contrast, that gibbeting was 'common practice in heinous cases' long before the eighteenth century, and although he only quotes a few examples, such as the gibbeted corpse described in Pepys's diary in 1661, Hartshorne's work on the period 1671-1690 which includes four well-evidenced cases of murderers being gibbeted in various parts of England, suggests that by the final third of the century this practice may well have been fairly widespread. ${ }^{82}$ As we will see in Chap. 3, gibbeting was fairly common by the time fuller newspaper coverage developed in the early-eighteenth century and may well have reached an all-time peak in the 1740s. Moreover, as soon as newspapers and printed Ordinary's Accounts become available towards the end of the seventeenth century reports of the gibbeting of London thieves and murderers immediately began to appear. In 1691 the Ordinary's Accounts describes the gibbeting at Mile End of the murderer James Selby and five years later the same source, and a London Newspaper-the Post Man, reported the gibbeting of Thomas Randall for murder and highway robbery at Kingsland 'where he is to hang in irons till his body be consumed'. 83 The Ordinary's Accounts of the hanging in 1684 of a notorious London highwayman and murderer reported that after his execution his body was 'cut down and put into a frame of iron ... and afterwards hung up again on the gibbet', giving further credence to the French visitor Henri Misson's observation in the late 1690s that 'robbers in the highway that have doubled their felony by the addition of murder to theft' usually had their bodies enclosed in 'several iron hoops' and exposed 'upon the gibbet'. ${ }^{84}$

The Admiralty Courts were also making quite widespread use of gibbeting by the beginning of the eighteenth century - a tradition that seems to have been a longstanding one and had originally included Admiralty courts outside London. ${ }^{85}$ Two very different forms of post-execution gibbeting were used by the Admiralty courts when they punished offenders 
for capital crimes committed in a maritime context. First, the bodies of all those hanged by the court were secured and left well below the high tide mark for three consecutive tides. Then, if selected for further punishment, the corpse would be hung in chains at a more permanent site on land. In July 1700, for example, ten pirates were hanged at Execution Dock on two gibbets specially erected 'within flood-mark', two of whom were then 'carried down in a boat in order to be Hang'd in Chains; one of them at halfway Tree between this City and Graves-End, and the other at the Hope'. ${ }^{86}$ In the same month the London newspapers also reported the gibbeting at Mile End of two offenders found guilty of murder by the Old Bailey judges, ${ }^{87}$ and since we also have evidence of two further gibbetings in metropolis in 1700 and 1701 - one being the hanging in chains of Captain Kidd at Tilbury ${ }^{88}$ - gibbeting was clearly established as a fairly frequent metropolitan occurrence by the end of the seventeenth century, even though the precise numbers of involved, and how those numbers varied between that century and the eighteenth, remain very difficult to establish.

The post-execution dissection of the condemned person's body (the detailed history of which is the subject Elizabeth Hurren's recent volume $)^{89}$ also developed as a significant element of capital punishment procedures in the early modern period. Much of the original impetus for this development came from medical institutions. As medical training gradually became more sophisticated in the early modern period and as the study of anatomy rose in importance because of the growing belief that it was a vital part of a surgeon's training, ${ }^{90}$ corpses came to be increasingly seen as valuable commodities and the bodies of executed criminals began to have a significant role in the mixed (and often makeshift) economy that developed to supply cadavers to those who needed them. ${ }^{91}$ The custom of giving the corpses of executed criminals to selected members of the medical profession was well established by the late-seventeenth century. ${ }^{92}$ As early as 1506 the Edinburgh Guild of Surgeons and Barbers was granted the body of at least one executed felon a year, and in 1540 the newly formed London Company of Barbers and Surgeons was given the annual right to four such corpses. ${ }^{93}$ In the following decade a similar level of provision was made available to Caius College Cambridge and by the mid-1560s the Royal College of Physicians had also been granted the bodies of four of those 'condemned and put to death for Theft, Murder or any other Felony' in the City of London, Middlesex 'or anywhere else 
within 16 miles of the said City'. This was increased to six bodies in 1641, the entire county of Surrey being added to the catchment area. ${ }^{94}$

The transformation of the surgeons' involvement in the execution process - from the marginal, sporadic and scarcely visible role they played in the sixteenth century to the very different, official and highly visible role they regularly enacted after the Murder Act-was a lengthy and uneven process. The surgeons' need for cadavers drew them gradually, but inexorably, into a deeper involvement in the criminal justice process. In the sixteenth and early-seventeenth centuries the surgeons took such a small proportion of the very large number of bodies that died on the gallows that their profile remained extremely low and they experienced very little hostility. ${ }^{95}$ However, as the number of felons being executed fell drastically in the mid- to late-seventeenth century, ${ }^{96}$ and as the surgeons' increasing needs continued to stimulate the market in corpses, the activities of the surgeons and those they employed to collect the bodies of the condemned from the gallows became more conspicuous and began to draw the anger of the crowd. By the end of the seventeenth century, Jonathan Sawday has argued, a 'crisis in the provision of corpses for the various anatomy schools' was beginning to develop. ${ }^{97}$ Though we know very little about the precise number of criminal corpses that were being used by the surgeons at this point, they were clearly not confining themselves to the quotas formally allowed them by the authorities. By the 1690s there is evidence that some of the condemned were selling their bodies to the surgeons before their executions, ${ }^{98}$ and in 1700 a foreign observer noted that that if any bodies were left unclaimed by family or friends after an execution they were 'sold to the surgeons to be dissected'. ${ }^{99}$ Their growing visibility in the early-eighteenth century, combined with that the fact that the surgeons increasingly paid their beadles and porters considerable sums to also collect the corpses of criminals who did have family and friends (who were themselves often deeply opposed to dissection), played a key role in creating the conflicts expressed in the Tyburn riots against the surgeons that Peter Linebaugh has shown were so frequent in the first half of the eighteenth century. 100

However, the hostility of the crowd was not the only problem the surgeons faced in their attempts to obtain the corpses of criminals executed at Tyburn. They also competed between themselves. In 1710 the President of the London College of Physicians expressed anger at 'the connivance of the Sheriff's Officers' who allowed a body that was supposed to be given to the College 'to be violently taken away and carried to St. Thomas's 
Hospital where it was privately dissected' ${ }^{101}$ By the 1720s the College of Physicians was so angry at the failure of the sheriff's officers to actively assist them in securing even the small number of criminal corpses they were legally entitled to, that they obtained specific orders from the City authorities in an attempt to ensure that they were given that assistance. The battles between the crowd and the surgeons, and between the rival groups among the anatomists themselves, continued despite the City's intervention and the notices they put into the papers threatening to prosecute under the Riot Act. However, the College of Physicians bitter complaints in 1720 that 'the Sheriff's Officers pretend that they are not obliged to secure and detain such bodies for the College', ${ }^{102}$ suggest that the problem lay partly in the surgeon's ambivalent status within the criminal justice system in the years before the Murder Act.

Although Ruth Richardson has argued that the privileged access to criminal corpses given to the surgeons from the sixteenth century onwards meant that 'dissection became recognized in law as a punishment' and that 'dissection was added to the array of punishments available to the bench', ${ }^{103}$ in practice the situation was much more fluid. As Sawday has pointed out, dissection had only a 'quasi-legal status' until the Murder Act and the terms 'penal dissection' or 'penal anatomy' can therefore only be properly applied to the situation after that act. Before 1752 dissection very rarely, if ever, appeared in the formal sentences recorded by the courts, but this did not mean that it had no impact on the experience of the condemned or on thinking about penal policy. The post-execution punishments of dissection and hanging in chains were well established by 1700 as the main forms of aggravated death penalty imposed on murderers and property offenders. However, their supremacy was not assured at this point. Several waves of pamphlets and articles explored various other options during the first half of the eighteenth century, many of which argued strongly for more continental (and from the point of view of the condemned more painful) solutions, and it is to these works that we now turn in Chap. 2.

\section{Notes}

1. E. Hurren, Dissecting the Criminal Corpse: Staging Post-execution Punishment in Early Modern England (London, 2016), S. Tarlow, Hung in Chains; The Golden and Ghoulish Age of the Gibbet in Britain (Forthcoming, Palgrave 2017). 
2. Hurren, Dissecting; Tarlow, Hung; R. Ward (ed.), A Global History of Execution and the Criminal Corpse (Basingstoke, 2015); O. Davies and F. Matteoni Executing Magic: The Power of Criminal Bodies (London, Palgrave forthcoming).

3. D. Garland, 'Modes of Capital Punishment: The Death Penalty in Historical Perspective' in D. Garland, R. McGowen and M. Meranze (eds.), America's Death Penalty; Between Past and Present (New York, 2011), pp. 30-71; M. Foucault, Discipline and Punish: The Birth of the Prison (London, 1979).

4. V. Gatrell, The Hanging Tree (Oxford, 1994).

5. P. Spierenburg, The Spectacle of Suffering (Cambridge, 1984); Foucault, Discipline and Punish; D. Garland, Punishment and Modern Society; A Study in Social Theory (Oxford, 1990), pp. 131-176 and 213-248.

6. D. Hay, 'Property, Authority and the Criminal law' in D. Hay, P. Linebaugh, E.P. Thompson and C. Winslow (eds.), Albion's Fatal Tree (London, 1975); Gatrell, The Hanging Tree, p. 32.

7. Hay, 'Property', pp. 17-18.

8. Gatrell, The Hanging Tree. For an excellent review see R. McGowen, 'Revisiting the Hanging Tree; Gatrell on Emotion and History' British Journal of Criminology, 40 (2000), pp. 1-13; T. Laqueur, 'Crowds, Carnival and the State in English Executions 1604-1868' in A. Beier, D. Cannadine and J. Rosenheim (eds.), The First Modern Society (Cambridge, 1989), pp. 305-355.

9. L. Radzinowicz, A History of English Criminal Law and its Administration from 1750, (London, 5 Vols., 1948-1986) 1; R. McGowen, 'A Powerful Sympathy: Terror, the Prison and Humanitarian Reform in Early Nineteenth-Century Britain' Journal of British Studies, 25 (1986), pp. 312334; R. McGowen, 'The Body and Punishment in Eighteenth-Century England' Journal of Modern History, 59 (1987). The role of religion in debates about the death penalty has also attracted considerable attentionR. Follett, Evangelicalism, Penal Theory and the Politics of Criminal Law Reform in England, 1808-1830 (Basingstoke, 2001); H. Potter, Hanging in Judgement: Religion and the Death Penalty in England (London, 1993).

10. P. King, Crime, Justice and Discretion in England 1740-1820 (Oxford, 2000); Hay, 'Property', p. 22; D. Hay, 'Writing about the Death Penalty' Legal History, 10 (2006), pp. 35-51; D. Hay, 'Hanging and the English Judges: The Judicial Politics of Retention and Abolition' in Garland, McGowen and Meranze (eds.), America's Death Penalty; D. Gray and P. King 'The Killing of Constable Linnell: The Impact of Xenophobia and of Elite Connections on Eighteenth-Century Justice' Family and Community History, 16 (2013). 
11. S. Devereaux, 'The Abolition of the Burning of Women Reconsidered' Crime, Histoire \& Societes/Crime, History and Societies, 9 (2005), pp. 1-22; R. Campbell, 'Sentence of Death by Burning for Women' Journal of Legal History, 5 (1984), p. 44-59.

12. Gatrell, The Hanging Tree, pp. 87-91, 255-257, 267-269; F. McLynn, Crime and Punishment in Eighteenth-Century England (London, 1989), pp. 272-274; Potter, Hanging in Judgement, p. 8; Radzinowicz, A History, 1, pp. 206-227; P. Rawlings, Crime and Power: A History of Criminal Justice 1688-1998 (Harlow, 1999), p. 49.

13. R. McGowen, 'The Problem of Punishment in Eighteenth-Century England' in S. Devereaux and P. Griffiths (eds.), Penal Practice and Culture 1500-1900; Punishing the English (Basingstoke, 2004), pp. 210231 and R. McGowen, 'Making Examples and the Crisis of Punishment in Mid-Eighteenth-Century England' in D. Lemmings (ed.), The British and Their Laws in the Eighteenth Century (Woodbridge, 2005), pp. 182-205.

14. J. Beattie, Policing and Punishment in London 1660-1750; Urban Crime and the Limits of Terror, (Oxford, 2001), p. 321 contains only passing reference to this subject. J. Beattie, Crime and the Courts in England 1660-1800, (Oxford, 1986), pp. 488-490 uses 3 main pamphlets. His later discussion of the Murder Act debates (pp. 525-530) draws on some further material. Two of the same pamphlets are quoted by D. Lemmings, Law and Government during the Long Eighteenth Century (Basingstoke, 2011), pp. 95-96; Radzinowicz, A History, 1, p. 38.

15. Radzinowicz, A History, 1, p. 238; J. Potter, The Fatal Gallows Tree (London, 1965), p. 71 describes these writers as 'fringe groups of blood-thirsty fanatics'.

16. Beattie, Crime, pp. 525-530; R. Ward, Print Culture, Crime and Justice in Eighteenth-Century London (London, 2014), pp. 157-203: R. Richardson, Death, Dissection and the Destitute (London, 1989).

17. One particular moment is, however, the subject of two interesting recent articles-R. Ward, 'The Criminal Corpse, Anatomists and the Criminal Law: Parliamentary Attempts to Extend the Dissection of Offenders in Late Eighteenth-Century England' Journal of British Studies, 54 (2015), pp. 63-87; S. Devereaux, 'Inexperienced Humanitarians? William Wilberforce, William Pitt, and the Execution Crisis of the 1780s' Law and History Review, 33 (2015), pp. 839-885.

18. Spierenburg, The Spectacle of Suffering; R. Evans, Rituals of Retribution: Capital Punishment in Germany 1600-1987 (Oxford, 1996); Foucault, Discipline and Punish; P. Friedland, Seeing Justice Done: The Age of Spectacular Capital Punishment in France (Oxford, 2012).

19. Anon, Hanging Not Punishment Enough (London, 1701).

20. Radzinowicz, A History, 1, pp. 231-238; Beattie, Crime, pp. 488-490. 
21. Anon, Solon Secundus: Some Defects in the English Laws (London, 1695), p. 7. This pamphlet also considered other options such as life imprisonment and transportation.

22. G. Ollyffe, An Essay Humbly Offer'd, for An Act of Parliament to Prevent Capital Crimes (London, 1731), p. 7.

23. Gentleman's Magazine, 8 (1735), p. 286.

24. Derby Mercury, 3 May 1733, 17 April 1735, 4 Nov 1736-these were reproducing articles from a London publication-Wye's Letter-R. Wiles, Freshest Advices (Ohio, 1965), p. 200.

25. See Chap. 3 and Ward, 'The Criminal Corpse'; Devereaux, 'An Inexperienced Humanitarian?'

26. Beattie, Crime, pp. 538-618.

27. 25 Geo II, c.37.

28. See Chap. 3 for sources and analysis of the frequency of post-execution punishment.

29. P. King and R. Ward, 'Rethinking the Bloody Code in Eighteenth-Century Britain: Capital Punishment at the Centre and on the Periphery' Past and Present (2015) 228, pp. 159-205.

30. Gatrell, The Hanging Tree, pp. 267-269; D. Rumbelow, The Triple Tree: Newgate, Tyburn and Old Bailey (London, 1982), p. 158; Potter, Hanging in Judgment, p. 8.

31. N. Elias, The Civilizing Process, I. The History of Manners (Oxford 1978) and II. State Formation and Civilization (Oxford, 1978); Garland, Punishment and Modern Society, pp. 215-241 is the best review of Elias's influence on this field.

32. Spierenburg, The Spectacle of Suffering, p. x; Evans, Rituals, p. 15.

33. Friedland, Seeing Justice Done, p. 165.

34. Beattie, Crime, p. 530.

35. Ibid., p. 631.

36. J. Cockburn, 'Punishment and Brutalisation in the English Enlightenment' Law and History Review 12 (1994), p. 178.

37. R. Richardson, 'Popular Beliefs about the Dead Body' in C. Reeves (ed.), A Cultural History of the Human Body. Volume 4. In the Age of the Enlightenment (Oxford, 2010), pp. 99-100.

38. Ibid., p. 100.

39. Ward, Print Culture, p. 159.

40. Foucault, Discipline and Punish.

41. Ibid., p. 11.

42. Ibid., p. 8.

43. Garland, 'Modes'.

44. Ibid., p. 35.

45. Ibid., p. 30 . 
46. Ibid., pp. 36 and $41-42$.

47. Ibid., p. 31.

48. P. Jenkins, 'From Gallows to Prison? The Execution Rate in Early Modern England' Criminal Justice History, 7 (1986), pp. 51-71; J. Sharpe, Crime in Early Modern England 1550-1750 (Harlow, 1984), p. 65.

49. For a good recent summary see D. Grey, Crime, Policing and Punishment in England 1660-1914. (London, 2016), pp. 276-295.

50. Beattie, Crime, p. 620.

51. Beattie, Policing, p. 473.

52. Hay, 'Property' remains the seminal work. Key monographs include King, Crime, Justice; Beattie, Crime; Beattie, Policing; R. Shoemaker, The London Mob: Violence and Disorder in Eighteenth-century England (London, 2004) but much of the best work has been done in groups of articles most notably by Shoemaker, Hay, Devereaux and McGowen. Gray, Crime provides the most recent survey.

53. Garland, 'Modes', p. 30.

54. Gatrell, The Hanging Tree.

55. Garland, 'Modes', p. 49.

56. Gatrell, The Hanging Tree, p. 10; Gray, Crime, p. 284.

57. Gatrell, The Hanging Tree, pp. viii-ix.

58. S. Devereaux, 'England's "Bloody Code" in Crisis and Transition; Executions at the Old Bailey 1760-1837' Journal of the Canadian Historical Society/Revue de la Societe Historique du Canada 24, (2013), pp. 71-113.

59. Cockburn, 'Punishment', pp. 171-172.

60. Rawlings, Crime and Power, p. 49.

61. Military executions are excluded here. They require separate treatment and followed a different pattern. Executions in Hyde Park were quite frequently reported-Old England or the National Gazette, l February 1752. The punishment of suicides' corpses is also excluded see: Radzinowicz, $A$ History, 1, pp. 195-200; R. Houston, Punishing the Dead? Suicide, Lordship and Community in Britain 1500-1830 (Oxford, 2010).

62. 2 \& 3 William IV, c.75, and 4 \& 5 William IV, c.26.

63. G. Durston, Crime and Justice in Early Modern England: 1500-1750 (Chichester, 2004), p. 677.

64. W. Andrews, Bygone Punishments (London, 1899), p. 96.

65. Radzinowicz, A History, 1, p. 183.

66. Ibid., 1, pp. 223-224.

67. P. Spierenburg, 'The Body and the State; Early Modern Europe' in N. Morris and D. Rothman (eds.), The Oxford History of the Prison; The Practice of Punishment in Western Society (Oxford, 1995), p. 54. 
68. Andrews, Bygone Punishments, pp. 106-107; Radzinowicz, A History, 1, pp. 238-239.

69. Durston, Crime, p. 688.

70. Radzinowicz, A History, 1, pp. 213-214; Anon, The History of the Lives and Extraordinary Adventures of the Most Famous Pyrates, Highwaymen, Murderers (Portsmouth, 1772); J. Louthian, The Form of Process before the Court of Justiciary in Scotland (Edinburgh, 1732), p. 238; Rachel Bennett's Leicester Ph.D. 2015 'Capital Punishment and the Criminal Corpse in Scotland 1740-1834' discusses several eighteenth-century examples-see her forthcoming Palgrave volume.

71. Evans, Rituals, pp. 27-86, 193-234; Spierenburg, The Spectacle; Friedland, Seeing; J. Ruff, Violence in Early Modern Europe 1500-1800 (Cambridge, 2001), pp. 98-102.

72. On thirteenth-century evidence-S. Pegge in Gentlemen's Magazine (1789), pp. 65, 207-208; Radzinowicz, A History, 1, p. 213; Five Derbyshire offenders were gibbeted in 1341 alone. Until the later sixteenth century those condemned for particularly heinous premeditated murders might still be gibbeted alive. Andrews, Bygone Punishments, pp. 41-42, 74-78.

73. For a contemporary definition, Gentlemen's Magazine (1789), 65, p. 208.

74. Ibid., p. 208; On gibbeting alive as long disused by 1700-Old England or The National Gazette, 1 February 1752.

75. Radzinowicz, A History, 1, p. 214.

76. Gentleman's Magazine, 7 (1737), p. 187; Country Journal, 26 March 1736-1737.

77. D. Paton, 'Punishment, Crime and the Bodies of Slaves in Eighteenth-Century Jamaica' Journal of Social History, 31 (2001), pp. 931-939. Burning alive and the display of the severed heads, hands and quarters of slaves in public places also occurred in the American ColoniesS. Banner, The Death Penalty: An American History (Harvard, 2002), pp. 70-76.

78. Publicus in London Magazine, December 1746, p. 638; Philandros in British Journal, 2 April 1726. For pre-colonial aggravated death penalty rituals in Africa see S. Hind, 'Dismembering and Remembering the Body: Execution and Post-execution Display in Africa 1870-2000.' in Ward (ed.), A Global History, pp. 222-228.

79. A. Hartshorne, Hanging in Chains (New York, 1893), p. 71; J. Beattie, Crime, pp. 528-529.

80. Hartshorne, Hanging, p. 71.

81. Cockburn, 'Punishment', p. 160.

82. Durston, Crime, pp. 669-670; Andrews, Bygone Punishments, pp. 43-44; Hartshorne, Hanging, pp. 53-54. 
83. Post Man and the Historical Account, 28 January 1696.

84. H. Misson, Memoirs and Observations in his Travels over England (London, 1719) recording journeys in 1697-1698.

85. On the Humber Admiralty Court's fifteenth-century use of gibbeting; Andrews, Bygone Punishments, pp. 3-4.

86. Flying Post, 13 July 1700.

87. London Post with Intelligence Foreign and Domestic, 19 July 1700.

88. R. Cavendish, 'Execution of Captain Kidd' History Today, 51 (May 2001) p. 53; Hartishorne, Hanging, pp. 53-71.

89. Hurren, Dissecting.

90. Anatomic knowledge was increasingly seen as an important component in surgeons' training: R. Porter, Disease, Medicine and Society in England 1550-1860 (Cambridge, 1993), pp. 28-29.

91. R. Richardson, Death, pp. 32-35.

92. On seventeenth-century practice K. Cregan, 'Early Modern Anatomy and the Queen's Body Natural: The Sovereign Subject' Body and Society, 13 (2007), pp. 51-53.

93. J. Sawday, The Body Emblazoned: Dissection and the Human Body in Renaissance Culture (London, 1995), pp. 56-57.

94. Ibid., p. 56; A Bill for ... Providing a Remedy for the ... College of Physicians in London to have the Bodies of Persons Executed for Felony (London, 1720), p. 5.

95. Sawday, The Body, pp. 56-57; Cockburn, 'Punishment', p. 170.

96. J. Sharpe, Crime in Early Modern England 1550-1750, (London, 1984) p. 85 .

97. Sawday, The Body, p. 57.

98. J. Cockburn, 'Punishment'; J. Sharpe, 'Last Dying Speeches: Religion, Ideology and Public Execution in Seventeenth-Century England' Past and Present, 107 (1985), p. 149.

99. Durston, Crime, 668; Beattie, Crime, p. 527.

100. Cregan, 'Early Modern', p. 63 argues the surgeons were not vigorously opposed until after 1660; P. Linebaugh, 'The Tyburn Riots Against the Surgeons' in D. Hay et al. (eds.) Albion's Fatal Tree, pp. 65-118.

101. T. Forbes, 'A Note on the Procurement of Bodies for Dissection at the Royal College of Physicians of London in 1694 and 1710' Journal of the History of Medicine, 1974, p. 334; on bodies being fought for to sell them on-Beattie, Crime, p. 527.

102. Monthly Chronicle, December 1729; London Gazette, 15 March, 13 September and 8 November 1729; A Bill for ... Providing, pp. 5-7; Linebaugh, 'The Tyburn', p. 74.

103. Richardson, Death, pp. 33-34. 
Open Access This chapter is licensed under the terms of the Creative Commons Attribution 4.0 International License (http://creativecommons.org/licenses/by/ $4.0 /$ ), which permits use, sharing, adaptation, distribution and reproduction in any medium or format, as long as you give appropriate credit to the original author(s) and the source, provide a link to the Creative Commons license and indicate if changes were made.

The images or other third party material in this chapter are included in the chapter's Creative Commons license, unless indicated otherwise in a credit line to the material. If material is not included in the chapter's Creative Commons license and your intended use is not permitted by statutory regulation or exceeds the permitted use, you will need to obtain permission directly from the copyright holder.

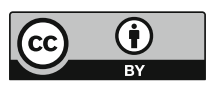

